\title{
Pertumbuhan Bibit Kelapa Sawit pada Tanah Gambut Berbagai Ketinggian Genangan
}

\section{The Growth of Oil Palm Seedling on Peat Soil in Various of Flooding Height}

\author{
Holidi $^{1,2^{*}}$, Etty Safriyani ${ }^{2}$, Warjiyanto ${ }^{2}$, Sutejo ${ }^{2}$ \\ ${ }^{1}$ Mahasiswa Program Doktor Ilmu Lingkungan Universitas Sriwijaya \\ ${ }^{2}$ Dosen Fakultas Pertanian Universitas Musi Rawas \\ *email : holidi@fp.unmura.ac.id
}

\begin{abstract}
The area of dry land for crop cultivation is limited, so peatland would be an alternative development. Adaptation of plant oil palm on the length inundation need to be investigated. This study aims to determine the growth response of oil palm seedlings in peat with some duration of flooding. The research was conducted in the experimental farm of the Faculty of Agriculture, University of Musi Rawas at an altitude of $110 \mathrm{~m}$ above sea level on March to June 2014. This study used a randomized block design (RBD) consists of six treatments and four replications. Treatment includes without flooding, duration of flooding 10, 20, 30, 40 and 50 days. The results showed that oil palm seedlings can survive up to 50 days of flooding. Long flooding inhibits the growth of plant height, number of leaves, reducing the amount of leaf chlorophyll. Flooding also causes morphological changes in the root of the formation of adventitious shoots.
\end{abstract}

Keywords: Oil Palm, Seedling, Flooding Duration

\section{INTISARI}

Luas areal lahan kering untuk budidaya perkebunan yang terbatas, sehingga lahan basah yang terkatagori tanah gambut menjadi alternative pengembangan. Adaptasi tanaman kelapa sawit terhadap lama genangan perlu diteliti. Penelitian ini bertujuan untuk mengetahui respon pertumbuhan bibit kelapa sawit di tanah gambut dengan beberapa durasi genangan. Penelitian ini dilaksanakan di kebun percobaan Fakultas Pertanian Universitas Musi Rawas pada ketinggian $110 \mathrm{~m}$ dpl pada bulan Maret sampai Juni 2014. Penelitian ini menggunakan Rancangan Acak Kelompok (RAK) non factorial terdiri enam perlakuan dan empat ulangan. Perlakuan meliputi tanpa genangan, lama genangan 10, 20, 30, 40 dan 50 hari. Hasil penelitian menunjukkan bahwa bibit kelapa sawit dapat bertahan hidup sampai 50 hari genangan. Lama genangan menghambat pertumbuhan tinggi tanaman, jumlah daun, mengurangi jumlah klorofil daun. Genangan juga menyebabkan perubahan morfologi akar dengan terbentuknya tunas adventif.

Kata kunci: Sawit, Seedling, Lama Penggenangan

\section{PENDAHULUAN}

Tanaman kelapa sawit adalah salah satu unggulan perkebunan Indonesia dengan luas mencapai 9,57 juta hektar pada tahun 2012 (Kementerian Pertanian, 2013). Mengingat lahan kering yang terbatas maka pengembangan kelapa sawit beralih ke lahan basah yang terkatagori tanah gambut (Najiyati, Muslihat, dan Suryadiputra, 2005). Luas sebaran potensi endapan gambut Indonesia mencapai 7,5 juta hektar (Tjahyono, 2006). Dengan demikian usaha untuk pengembangan kelapa sawit di lahan gambut menjadi pilihan.

Tanah gambut merupakan adalah tanah yang terbentuk pada kondisi anaerob di lahan rawa. Tanah gambut mempunyai kandungan organik lebih dari 50 persen dan merupakan akumulasi sisa tanaman (Galbraith et al., 2005). Lahan gambut baik di daerah rawa pasang surut maupun lebak selalu mengalami genangan secara periodik (Najiyati, Muslihat, dan Suryadiputra, 2005). Pemanfaatan lahan gambut untuk budidaya kelapa 
sawit mempunyai banyak kendala salah satunya berkaitan dengan adanya genangan.

Tanaman yang tergenang akan mengalami gangguan fisiologis karena terjadi proses metabolism secara anaerob pada tanaman. Pada tanaman yang tidak toleran maka akan mengalami gangguan secara permanen (Colmer and Voesenek, 2009). Kondisi optimal untuk pertumbuhan tanaman dan melakukan respirasi dapat dicapai pada tingkat muka air yang tepat (Berglund and Berglund, 2011). Tanaman adalah organisme aerobic dan membutuhan oksigen untuk bertahan hidup, dengan demikian jika kondisi tergenang maka tanaman akan menderita karena kekurangan oksigen.Bila sebagian tanaman tergenang seperti akar maka proses metabolisme tanaman secara keseluruhan akan terganggu (Taiz and Zeiger, 2002).Tanaman kelapa sawit merupakan tanaman yang terkatagori tanaman toleran terhadap genangan, sampai 30 hari genangan tidak mengalami kerusakan yang parah pada daun (Dewi, 2009). Namun demikian tanaman kelapa sawit untuk tumbuh dengan sehat tidak boleh tergenang karena akan menghambat pertumbuhannya.

Penelitian ini bertujuan untuk mengevaluasi respon pertumbuhan bibit kelapa sawit pada media tanah gambut dengan berbagai lama genangan baik secara morfologis maupun fisiologis.

\section{BAHAN DAN METODE}

Penelitian ini telah dilaksanakan di kebun percobaan Fakultas Pertanian Universitas Musi Rawas pada ketinggian $110 \mathrm{~m}$ dpl dari bulan Maret sampai Juni tahun 2014. Bahan yang digunakan adalah bibit tanaman kelapa sawit umur 6 bulan varietas DxP TN-1, Air bersih, pupuk pelengkap cair, kayu, papan, plastik terpal, alkohol $95 \%$, kertas saring dan pupuk NPK 1515-15. Sedangkan alat-alat yang digunakan adalah kotak genangan, alat ukur, cangkul dan gergaji, ember dan martil.

Penelitian ini menggunakan Rancangan Acak Kelompok (RAK) non factorial yang diulang sebanyak empat kali (Gomes and Gomes, 1995). Perlakuan meliputi tanpa genangan (G0), lama genangan 10 hari (G1), 20 hari (G2), 30 hari (G3), 40 hari (G4), dan 50 hari (G5).

Bibit dipindahkan ke polybag ukuran $10 \mathrm{~kg}$ yang berisi tanah gambut dengan kandungan kimia dapat dilihat pada Lampiran 1. Media genangan terbuat dari plastik yang dibentuk menyerupai kolam dengan kerangka papan dengan ukuran $2 \mathrm{~m} \times 2 \mathrm{~m} \times 0,5 \mathrm{~m}$. Selanjutnya media enggenangan diisi dengan air hingga sampai bol tanaman sawit. Lama genangan sesuai perlakuan dengan pemberian genangan 50 hari diberi genangan terlebih dahulu kemudian menyusul perlakua lainnya. Pemeliharaan dilakukan dengan cara mempertahankan tinggi genangan, penambahan air jika terjadi penurunan tinggi genangan.Penelitian diakhiri setelah 50 hari dari awal penelitian.

Pertambahan tinggi diukur dengan cara mengukur tinggi tanaman pada awal dan akhir penelitian. Pertambahan jumlah daun (helai), diukur dengan cara menghitung jumlah daun yang terbentuk pada awal dan akhir penelitian.

Diameter batang $(\mathrm{mm})$, dilakukan dengan cara mengukur diameter bol bibit sawit dengan

Tabel 1. Hasil analisis kimia tanah gambut yang digunakan

\begin{tabular}{cccc}
\hline No & Komponen & Satuan & Hasil analisis \\
\hline & & & \\
1 & Kadar air & $\%$ & 6,1 \\
2 & pH (H2O) & - & 3,2 \\
3 & pH KCl & - & 2,4 \\
4 & C-organik & $\%$ & 75,52 \\
5 & N-total & $\%$ & 0,72 \\
6 & P2O5 & ppm & 45,19 \\
7 & K-dd & me/100 & 0,42 \\
8 & Ca-dd & me/100 & 11,82 \\
9 & Md-dd & me/100 & 5,11 \\
10 & KTK & me/100 & 52,52 \\
11 & Al-dd & me/100 & 6,04 \\
12 & H-dd & me/100 & 3,18
\end{tabular}


menggunakan jangka sorong. Dilaksanakan pada akhir penelitian. Berat basah berangkasan bibit didapatkan dengan cara menimbang seluruh bibit tanaman dilakukan pada akhir penelitian. Jumlah akar dan panjang akar dilakukan pada akhir penelitian.

Kadar klorofil daun kelapa sawit dilakukan pada daun nomor tiga dari pucuk menggunakan metode spektrofometer pada panjang gelombang $649 \mathrm{~nm}$ dan $665 \mathrm{~nm}$ dilakukan pada akhir penelitian.
HASIL DAN PEMBAHASAN

Hasil analisis keragaman (Tabel 1) menunjukkan bahwa perlakuan lama penggenangan berpengaruh nyata terhadap pertambahan tinggi tanaman. Hasil uji BNJ (Tabel 2) menunjukkan bahwa perlakuan G0 berbeda tidak nyata dengan perlakuan G1 dan berbeda nyata dengan perlakuan lainnya. Pertambahan tinggi tanaman tertinggi terdapat pada perlakuan G0 yaitu $6,31 \mathrm{~cm}$ dan terendah pada perlakuan G4 yaitu 4,27 cm (Gambar1).

Tabel 2. Hasil Analisis Keragaman Respon Pertumbuhan Bibit Tanaman Kelapa Sawit (Elaeis guineensis Jack) terhadap Lama Genangan

\begin{tabular}{clcc}
\hline No & \multicolumn{1}{c}{ Peubah yang diamati } & G & KK \\
\hline 1. & Pertambahan Tinggi Tanaman $(\mathrm{cm})$ & $4,00^{*}$ & 14,44 \\
2. & Pertambahan Jumlah Pelepah Daun (helai) & $1,49 \mathrm{tn}$ & 22,56 \\
3. & Berat Basah Berangkasan (g) & $0,86 \mathrm{tn}$ & 21,84 \\
4. & Jumlah Klorofil (mg-1) & $18,71^{* *}$ & 20.63 \\
\hline
\end{tabular}

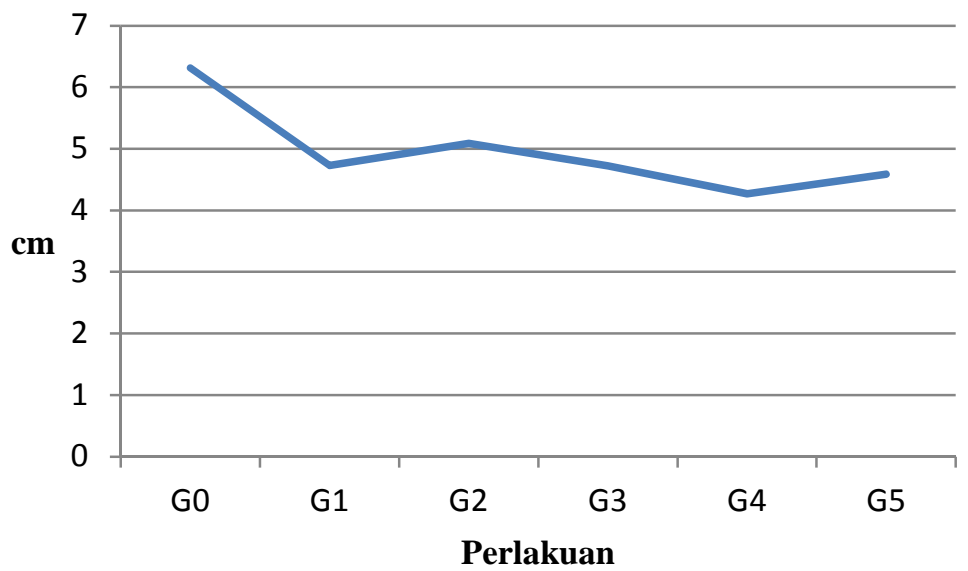

Gambar 1. Pertumbuhan tinggi tanaman pada setiap perlakuan

Hasil analisis keragaman menunjukkan bahwa perlakuan lama penggenangan berpengaruh tidak nyata terhadap pertambahan jumlah pelepah daun. Hasil tabulasi data menunjukkan bahwa perlakuan
G0 menghasilkan pertambahan jumlah pelepah daun terbanyak yaitu 2,25 helai dan paling sedikit pada perlakuan G4 yaitu 1,59 helai (Gambar 2).

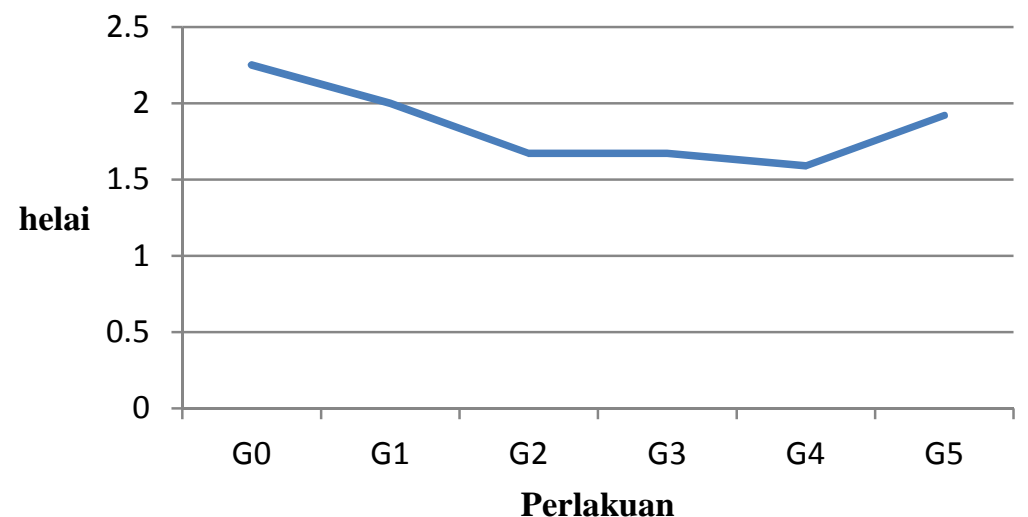

Gambar 2. Pertambahan jumlah daun pada setiap perlakuan 
Analisis keragaman menunjukkan bahwa perlakuan lama genangan berpengaruh tidak nyata terhadap berat basah berangkasan. Hasil tabulasi data menunjukkan bahwa perlakuan G3 menghasilkan berat basah berangkasan terberat yaitu 650,00 gram dan paling sedikit pada perlakuan G5 yaitu 487,50 g. Berat berangkasan basah pada setiap perlakuan dapat dilihat pada Gambar 3.
Hasil analisis keragaman menunjukkan bahwa perlakuan lama penggenangan berpengaruh sangat nyata terhadap jumlah klorofil. Hasil uji BNJ menunjukkan bahwa perlakuan G0 berbeda sangat nyata dengan G3, G4, dan G5 serta berbeda tidak nyata dengan G1 dan G2. Jumlah klorofil terbanyak terdapat pada G0 yaitu $56,23 \mathrm{mg}^{-1}$ dan paling sedikit pada perlakuan G5 yaitu $19,89 \mathrm{mg}$ 1. Jumlah klorofil daun pada setiap perlakuan dapat dilihat pada Gambar 4.

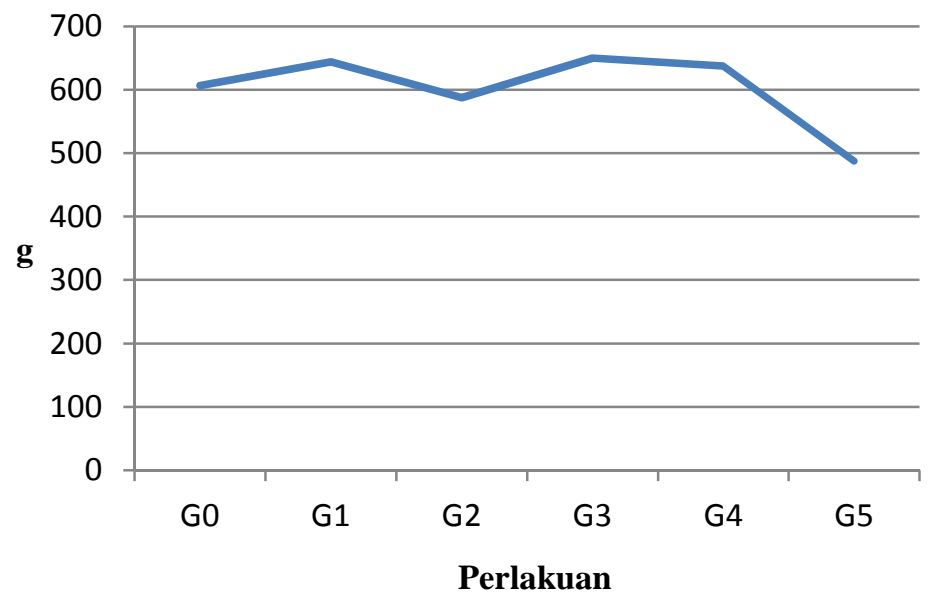

Gambar 3. Berat berangkasan basah

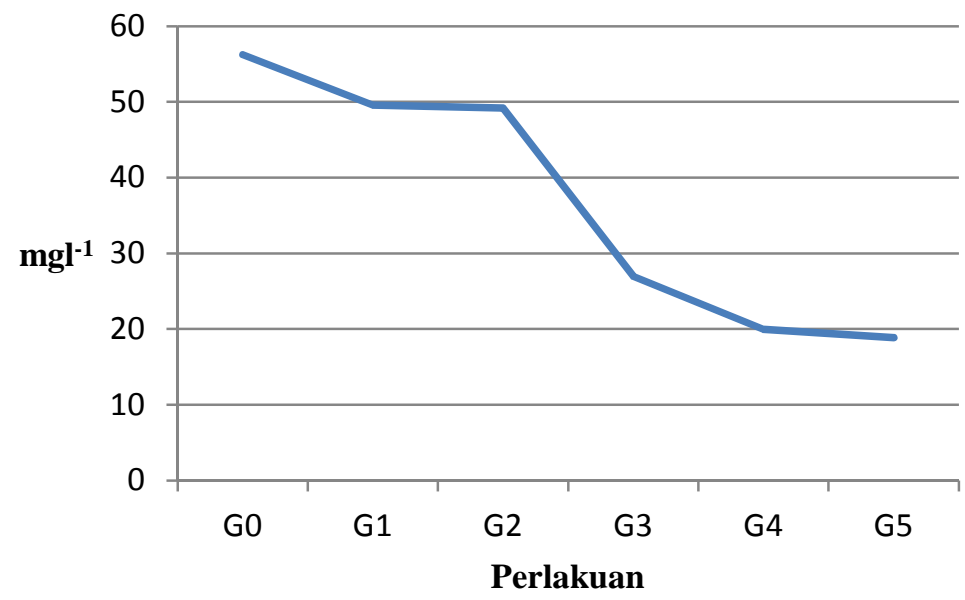

Gambar 4. Kadar Klorofil pada setiap perlakuan

Hasil pengamatan visual terhadap morfologi akar menunjukkan bahwa semakin lama digenangi maka semakin terlihat perubahan morfologi akar bibit tanaman sawit. Perubahan tersebut tampak pada warna akar dan munculnya akar adventif dari media tanam yang digenangi (Gambar 5).

Berdasarkan pengamatan menunjukkan bahwa semua tanaman yang diberi perlakuan genangan sampai 50 hari dapat bertahan hidup. Hal ini berarti tanaman kelapa sawit adalah tanaman yang teratagori tanaman sangat toleran terhadap genangan. Menurut Bratkovich et al., (1993), tanaman yang sangat toleran terhadap genangan mampu bertahan hidup sampai 3 bulan genangan. Menurut Colmer and Voesenek (2009) dan Dewi (2009), tanaman sawit merupakan tanaman yang toleran terhadap genangan dan dapat bertahan hidup dengan beradaptasi pada lingkungan yang tergenang. 
Lama genangan berpengaruh nyata terhadap pertambahan tinggi tanaman dan berpengaruh sangat nyata terhadap jumlah klorofil serta berpengaruh tidak nyata terhadap peubah lainnya. Hal ini disebabkan karena lama genangan mempengaruhi aktivitas penyerapan baik unsur hara maupun oksigen untuk kebutuhan tanaman. Menurut Grichko and Glick (2011) dan Visser and Voesenek (2004), genangan pada tanah menyebabkan akar tanaman mengalami gangguan dalam respirasi, penyerapan unsur hara dan metabolisme tanaman secara keseluruhan. Menurut Taiz and Zeiger (2002), penyerapan unsur hara oleh akar yang terganggu akibat genangan menyebabkan terjadinya defisiensi unsur hara pada tanaman. Unsur hara yang kurang pada tanaman menyebabkan pembentukan klorofil terganggu dan kadar klorofil pada daun menjadi turun.

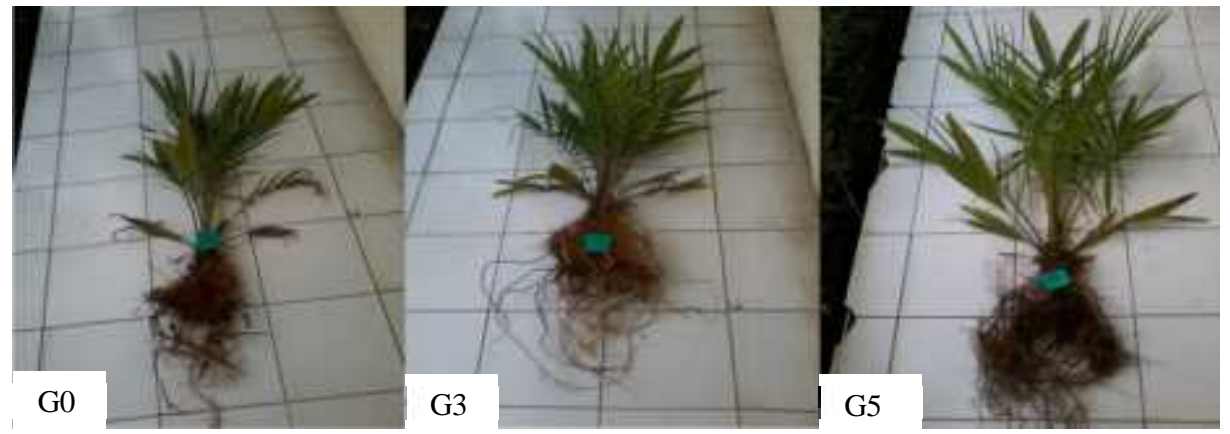

Gambar 5. Morfologi akar setelah diberi perlakuan lama genangan

Perlakuan lama genangan berpengaruh nyata terhadap pertambahan tinggi tanaman. Semakin lama tanaman tergenang maka periode stess tanaman menjadi semakin lama. Pada periode stress tersebut tanaman mengalami gangguan fisiologis.Menurut Pucciariella et al., 2014), tanaman akan terganggu pertumbuhannya karena akar yang mengalami anoksia. Kondisi ini menyebabkan tanaman akan mengalami proses anaerob dan pertumbuhan tanaman akan terhambat akibat proses metabolisme tanaman terganggu.

Pada kondisi tergenang, tanah akan jenuh dengan air dan oksigen di dalam tana menjadi berkurang akibat pori-pori tanah dipenuhi oleh air (Galbraith, Amerasinghe and Lee, 2005). Ketika akar tanaman tergenang maka proses respirasi akar dan penyerapan unsur hara menjadi terbatas. Akibat gangguan respirasi dan penyerapan maka tanaman mengalami gangguan proses metabolisme secara keseluruhan. Selama periode ini tanaman memanfaatkan unsur hara yang ada pada tanaman (Visser et al., 2003).

Kadar klorofil tanaman semakin turun dengan semakin dekatnya muka air dengan permukaan tanah. Tanaman kelapa sawit yang tidak diberi perlakuan (kontrol) mempunyai kadar klorofil daun sebesar 28,09 $\mathrm{mg} / \mathrm{l}$ sedangkan untuk perlakuan T1, T2, T3, T4, dan T5 masing-masing 18,$35 ; 18,00 ; 12,97 ; 10,24$; dan 10,59 mg/l. Penurunan terjadi berhubungan dengan semakin besarnya bagian tanaman yang tergenang. Proses respirasi dan penyerapan hara yang terganggu akan semakin besar akibat semakin banyaknya bagian akar yang tergenang (Taiz and Zeiger, 2002).

Klorofil merupakan pigmen warna hijau pada tanaman berperan penting pada fotosintesis dengan menyerap dan mengubah energi cahaya menjadi energi kimia. Ada tiga peranan utama klorofil yaitu memanfaatkan energi cahaya matahari, memacu penyerapan $\mathrm{CO}_{2}$ menjadi karbohidrat, melalui proses anabolisme karbohidrat diubah menjadi protein, lemak, asam nukleat, dan molekul organik lainnya (Hopkins and Hunner, 2008). Akibat rendahnya kadar klorofil dan rendahnya unsur hara maka proses fotosintesis menjadi terganggu dan fotosintat yang dihasilkan menjadi turun.

Pada peubah panjang akar dan jumlah akar menunjukkan bahwa adanya kecenderungan pertambahan jumlah akar dan panjang akar semakin bertambah karena pengaruh besarnya bagian akar yang tergenang. Tanaman yang mengalami anoksia akan beradaptasi secara morfologi dengan menambah jumlah akar dan memperpanjang akar. Menurut Visser et al. ( 2004), tanaman yang terganggu akibat genangan akan beradaptasi dengan mengeluarkan akar lebih banyak karena tanaman beradaptasi untuk mendapatkan oksigen yang lebih banyak. 


\section{KESIMPULAN}

Tanaman kelapa sawit dapat bertahan hidup pada kondisi tergenang sampai durasi 50 hari. Pemberian genangan pada tanaman kelapa sawit menghambat pertumbuhan tinggi, jumlah daun, diameter batang dan mengurangi kadar klorofil pada daun. Semakin lama tanaman tergenang maka semakin terhambat pertumbuhan tanaman.

\section{DAFTAR PUSTAKA}

Berglund, Orjan and Berglund, Kerstin. 2011. Influence of water table level and soil properties on emissions of greenhouse gases from cultivated peat soil. Soil biology \& biochemistry. 43:5.923-931.

Blom, C. W. P. M. and L.A.C.J. Voesenek. 1996. Flooding: the survival strategies of plants. Trends in Ecology \& Evolution. 11.290-295.

Bratkovich, Stephen., Burban, Lisa., Katovich, Steven., Locey, Craig., Pokorny, Jill., Wiest, Richard. 1993. Flooding and its effect on trees. Misc. Publ. Newtown Square, PA: U.S. Dept. of Agriculture, Forest Service,NorthernAreaState\&PrivateForestry. http://www.na.fs.fed.us/spfo/pubs/nresource/ flood/cover.htm. Diakses pada Januari 2012.

Colmer, T.D. and L.A.C.J. Voesenek. 2009. Flooding tolerance: suites of plant traits in variable environments. Functional Plant Biology.36.665-681.

Dewi, N. 2009. Respon bibit kelapa sawit terhadap lama penggenangan dan pupuk pelengkap cair. Agronobis. Vol 1 No 1.

Elmi, A.A., C. Madramootoo., M. Egoh,. A.Liu and C. Hamel. 2002. Environmental and agronomic implication of water table and nitrogen fertilization management. Journal of Environmental Quality. 31:6.
Galbraith, H., Amerasinghe, P ., and Lee, H.A. 2005. The effects of agricultural irrigation on wetland ecosystems in developing countries: a literature review. CA Discussion Paper 1 Colombo, Sri Lanka: Comprehensive Assessment Secretariat.

Gomes, A.K. dan Gomes. A.A. 1995. Prosedur Statistik untuk Penelitian Pertanian. UI Press.Jakarta.

Grichko,V.P. and B.R. Glick. 2001. Ethylene and flooding stress in plants. Plant Physio Bio Chem. 39 (1).

Hopkins, W. G. and Huner, NPA. 2008. Introduction to Plant Physiology. John Wiley \& Sons, Inc. The University of Western Ontario.

Kementerian Pertanian. 2013. Database Luas Areal Perkebunan. www.deptan.go.id. Diakses pada Maret 2014.

Najiyati, S., L. Muslihat dan INN.Suryadiputra. 2005. Panduan Pengelolaan Lahan Gambut Untuk Pertanian Berkelanjutan. Wetland International - Indonesia Programme.

Pucciariello, C., L.A.C.J. Voesenek., P. Perata and R. Sasidharan. 2014. Plant responses to flooding. Front Plant Sci. 5:226.

Taiz, L. and Eduardo. Zeiger. 2002. Plant Physiology. Third edition. Sinauer Associates. Sunderland.

Tjahjono, JAE. 2006. Kajian potensi endapan gambut Indonesia berdasarkan aspek lingkungan. Proceeding Pemaparan HasilHasil Kegiatan Lapangan dan Non Lapangan. Pusat Sumber Daya Geologi.

Visser, E.J.W. and L.A.C.J. Voesenek. 2004. Acclimation to soil flooding-sensing and signal-transduction. Plant and Soil. 254:197214. 